\title{
RE-CONCEPTUALIZING MOTHER TONGUE TUITION OF ESTONIAN ABROAD AS A transNational PHENOMENON
}

\author{
Maarja Siiner
}

\begin{abstract}
The governmental initiative called the Compatriots Programme, which supports language tuition in Estonian schools and societies abroad, reveals an increased interest in developing intergenerational language transmission in the growing Estonian diaspora. This transnational language political activity signals a new era in language policy, where nation states are increasingly decentralized by migration. The evaluation of the program furthermore reveals that organizing such schools requires a willingness to take language political agency, typically conducted by well-educated and well-integrated resourceful transnational multilingual parents. The present article outlines the results of an ethnographic study of the process of establishing the Estonian School in Copenhagen. This step has demanded a change in the mindset still prevailing in Estonia that language political activities, such as planning language acquisition, are solely the responsibility of the state. Since the prevailing language ideology in Denmark is not favorable towards multilingualism in migrant languages, intergenerational language transmission furthermore presupposes a feeling of ownership of the language and high language self-esteem.
\end{abstract}

Keywords: language policy, education policy, native language pedagogy, language contact, Denmark, Estonian

\section{The objective of the study}

The term mother tongue (hereafter MT) has different names in different state traditions and language regimes: heritage language(s), home language(s), immigrant language(s) and first language(s) are just a few examples (Pauwels 2007), signaling the different political status and migration history of the groups referred to in those terms. In Denmark MT (modersmål) is understood as the home language or the first language of a child living in Denmark that is not Danish. The term mother tongue 
tuition (hereafter MTT), Danish modersmålsundervisning, appeared in the Danish language acquisition political debates in 1970 and is now an even more contested term, as its position within the national curriculum has changed considerably. From previously being understood as a right to preserve one's home language and culture, MTT anno 2016 is a poorly developed subject with a vague position, in which the pupils and the mother tongue teachers have to invest considerable resources, since the state does not (Daugaard 2015). By contrast, in Estonia the term MT (emakeel) and MTT (emakeele ope) has traditionally referred to the teaching and learning of Estonian as $\mathrm{MT}^{1}$, while there is no single term in language acquisition planning respective to the Danish modersmålsundervisning, as there are different options for receiving tuition in home languages depending on the language and its status.

The concept 'minority language, or MT' is thus an expression of a relation between languages, not an essence of language (Cronin 1995). These relations are dynamic rather than static as the legal status of different languages and the linguistic order as such is a result of changes in the political, legal, socioeconomic, demographic etc. situation in a state (Hult, Pietikäinen 2014). The main objective of this article is to demonstrate that MTT is a transnational phenomenon shaped at the intersection of two different language regimes and state traditions, in terms of their teaching philosophies, national curricula etc. In my analysis of these traditions I am inspired by historical institutionalism (Sonntag, Cardinal 2015), which analyses how institutions are shaped by policies that are informed by historical events. The aim of the present paper is also to consider the dynamism of the language regimes (Pietikäinen, Pitkänen-Huhta 2014) and the agentive role of individuals, groups and institutions in language practices and ideologies as the starting point for the examination of the phenomenon of MTT of EU languages in the EU.

This dynamism and an ongoing reconceptualization of the linguistic order in time and space is best captured by ethnographic methods that place policies in the larger sociocultural context (McCarty 2011: 2). This approach investigates policy as a practice of power that operates at multiple levels, not only on the macro level of the state but also on the micro level of interpersonal communication and the meso level of community. The focus will in this paper be on the micro and meso level, i.e. how a language community is created and consists of individual language political actions. As an example I will use the organisation of MTT of Estonian in Copenhagen, Denmark. The study was carried out in 2015-2016 and applied ethnographic micro level methods of classroom observation and interviews with the Estonian MT teacher (hereafter ET), carried out in Estonian, and with the Head (hereafter HM) of the Mother Tongue School (Modersmålsskolen) in the Copenhagen municipality, carried out in Danish. Those interviewed were informed about being voluntary subjects of research and have signed informed consent forms, wherein they chose to remain anonymous. In addition, I have carried out an anonymous questionnaire in Estonian among the Estonian-speaking parents. All translations into English used in this article are mine. My aim was to map the conceptualizations of MT in relation to the existing policies and practices, both in Estonia and in Denmark, and to analyze the agency. I claim that MTT is as much about community building and creating a feeling of belonging as it is about language. Being a transnational phenomenon, the meaning of MTT cannot come from either the host or the home country, but has to be created anew. This presupposes an agentive role of both teachers and parents.

1721 Some examples can be found in the names of organisations like Emakeele Selts (the Mother Tongue Society), an organization operating in Estonia that brings together people working in or interested in the field of Estonian and related Finno-Ugrian languages; Eesti Emakeeleõpetajate Selts - Association of Estonian Language Teachers vs. Eesti keele kui Teise Keele Õpetajate Liit - Association of Teachers of Estonian as Second Language. 


\section{Theoretical basis: MTT as a transnational phenomenon}

MTT as a field of study has been viewed in Scandinavia from the points of different disciplines, ranging from psychology to education studies, exploring the effects of bior plurilingualism on children's linguistic and educational development (Daugaard 2015, Torpsten 2012, Kristjansdóttir 2006, Skutnabb-Kangas 2000). The present paper conceptually positions MTT within the domain of macro-sociolinguistic language policy research, a subfield of critical sociolinguistics that studies how states deal with minority and immigrant languages within the educational domain, in particular whether they provide assistance to these languages and what is the nature of this assistance (May 2015). Language policy research is also a field where applied linguistics meets political science to facilitate a better understanding of how state-initiated language policies are increasingly challenged by globalisation and transnational migration (Brown et al. 2017). By organizing of MTT I mean a language policy activity that is situated within the sociocultural and socioeconomic situation of both the host country and the country of origin (Daugaard 2015). MTT studies in Denmark focus mainly on languages from Third World countries, like Turkish or Pakistani. Present article will analyze MTT of an EU language, which is a specific case. According to the European Council Directive 77/486EEC (ECD), EU citizens have the right to maintain their language in other EU states, and in many cases the EU countries actively take part in shaping and supporting MTT of their state language in other EU countries. The choice of maintaining a minority or immigrant language is also influenced by the individual's everyday social practices of interpretations or meaning-making of past experiences and future expectations (Koreinik, Praakli 2017). It is widely attested that people who have a positive attitude towards maintaining their language maintain it better than those with less favorable attitudes, even in the same environment (Pauwels 2007).

Understanding multilinguals' language habits and choices, hereunder attaining or organizing MTT, has for a long time been interpreted within the context of migration typical for 20th century Europe. Presentations of European migration have focused on how migrants from outside of Europe adapt to social rules or are socially excluded in their places of immigration. Migrants who choose to maintain their linguistic and cultural distinctiveness over cultural adaptation tend to be a group that clusters in occupations at the lower end of the hierarchy of money, status and power (Barry 2001) and are often thus represented in negative terms in the public discourse. In the beginning of the new century it was increasingly recognized that some migrants did both - they maintained their language and thus various forms of contact with people and institutions in their places of origin, while also being active in the host country (Vertovec 2001: 574). To describe this type of cross-border social relations and strong bi-national migrant identity, the concept of transnationalism was introduced. The term denotes the process by which immigrants build social fields that link together their country of origin and their country of settlement" (Glick Schiller et al. 1992: 1). Low fare transportation options, expansion of communication technologies and software facilitate transnationalism, but developing a transnational identity depends on whether you are able to transform the migrant status into positive social capital in the home country (Nieswand 2014) 
and on the narratives about migration and compatriots in mass media and social communication channels (Pauwels 2007).

In Estonia the state supported initiatives like "Talented people, come home!" and the "Compatriots Programme" (Keskpaik 2013, Aksli et al. 2015) facilitating repatriation of Estonian migrants indicate on the one hand that the decreasing or "small Estonia" at home needs an increasing or "big Estonia" (Ehala 2014) abroad. However, as Aet Annist (2016) argues, these are meant only for those members of the "big Estonia" who are perceived as capable of making the "small Estonia" great through their success abroad. The vast majority of the group of Estonians who have migrated to the EU are either unemployed or work in low-income sectors (Tammaru, Eamets 2015). This group is not perceived as successful transnational commuters and is not the target group of the governmental actions mentioned above. They lack the social status abroad that can grant them positive ethnic capital at home. This group is more likely to cut their ties with Estonia or not make efforts to maintain these ties. By analyzing MTT as related to migrants' linguistic behavior and their social status and self-identification, we can see how political initiatives and migration narratives at home affect the choice of maintaining the language of origin and counteracting assimilation. The possession of both sufficient social capital abroad and ethnic capital at home are a necessary basis on which language political agency of language maintenance can grow (Koreinik, Praakli 2017).

\section{Mother tongue tuition in Denmark}

Contrary to Sweden, Denmark does not have a separate Language Act, and as such, the use and acquisition of languages are regulated within other legislation areas and affected by different, often conflicting political agendas and ideologies (Siiner 2012, 2010). Bergthora Kristjansdóttir, Anne Holmen and Michael S. Pedersen (2008) compared presentations of MTT of immigrant languages in educational policy to the information material "Teaching Danish to the children of Danish origin abroad" developed by the Danish Foreign Ministry. While the preservation of MT among the transnational Danes living abroad was framed as an asset in the latter, since it provides a bilingual Danish child with healthy identity, close connection to roots and a necessary basis for gaining good competences in the second language, the former argued that MTT to the bilingual immigrants in Denmark should not be supported. The rhetoric was colored by the new immigration policy of the new right wing government that linked bilingualism in immigrant languages to bilingual children's poor school achievement and to problems in becoming self-employed later on in life (Kristjánsdóttir et al. 2008).

Until the 1980s, the labour force exodus to the Scandinavian countries that began in the 1960s mostly drew people from the Middle East and Africa. MTT was introduced in the Danish curriculum in 1975, after Denmark had been receiving mainly labor immigrants for almost a decade. MTT was offered on equal terms, regardless of country of origin, to all bilingual children in primary school, as necessary for gaining good competences in Danish and preserving a healthy identity (Timm 2009). Starting from the 1990 os the rhetoric changed when the debates on the usefulness of MTT were at the heart of the heated debates on immigration. As a 
result of these debates, the new right wing government decided that the state should no longer subsidize MTT, and in the beginning of the new century approximately 62,000 bilingual children of non-EU origin lost their right to develop their mother tongue as an integral part of the public educational system from 2008 (Timm 2007). This resulted in a situation where MTT was offered only in two large cities with a higher concentration of immigrants, Copenhagen and Århus (Daugaard 2015, Timm 2007).

The debates on the usefulness of bilingualism or the ways to manage multilingualism in the primary school system continued and reached their peak in 2005 when the first results of OECD's PISA evaluations in Denmark arrived. The results showed that the children of migrants demonstrated poorer academic achievements in reading and comprehension compared to Danes (Egelund 2012). This led to a number of further amendments in language education policies in Denmark that aimed at minimizing the potentially negative effects of MTT, such as introducing obligatory language screening of bilingual children starting from age 3 and lasting throughout primary education (Siiner 2012). Within public media and political discourse bilingualism was increasingly represented as a disability (Holmen, Jørgensen 2010, Holmen 1997). Public hostility towards certain types of private or public multilingualism is not new and has in many parts of the world led to a view on multilingualism especially in immigrant or minority languages as limiting one's possibilities for social mobility (May 2015). This has also colored the perception of MTT or maintenance of minority languages as a willful form of ghettoization of minority groups and building of language borders as obstacles to communication and integration (Canagarajah 2005).

According to the European Council Directive 77/486EEC (ECD), the official EU languages have to be promoted within all other EU member states, meaning that they in principle enjoy governmental subsidies for their instruction in Denmark. The organization of MTT in municipalities is at the same time framed by the same language education infrastructure, which is colored by the ideological debates on bilingualism in immigrant languages as socially stigmatizing, as an obstacle rather than an asset with mainly negative connotations like lower social status, poor academic achievement, unemployment, and higher criminality rates (Holmen, Jørgensen 2010). Success and realisation of MTT, as of any educational initiative, needs infrastructural stability and the involvement of families (Kramsch 2002, Cummings 2000). Although the Copenhagen municipality continued to subsidise MTT of all immigrant languages spoken in the municipality, no department of the city government systematically worked on availability of information, sufficient allocation of materials and teaching resources on municipal and school levels or for advocating a general supportive public discourse on multilingualism.

The area of MTT remained underdeveloped and without organisational support and was not conceptualized until 2015 when Modersmålsskolen was established in the Tove Ditlevsen primary school in Copenhagen to facilitate MTT for the children of the increasing number of new 'transnationals' from the EU. For the first time, the majority of MTT classes take place at the same location and at the same time, making it possible for MT teachers and multilingual children to meet. "[This school] is clearly about being proud speaking several languages and having a positive identity about your mother tongue" (HM). The existence of an organisational 
frame also facilitates infrastructural development: ".. people do not know about the school. We need to work on spreading the word” (HM). Below I will return to this discussion.

\section{The endangered majority language in Estonia}

Since the national awakening in the 19th century, the Estonian language has created the basis for the national culture and establishment and survival of the nation state (Raag 1999). It regained the status of the only official language in 1991 but is still perceived as being under constant threat, an "endangered majority language" (Kalmus 2003). The number of Estonians living abroad has increased considerably since the 1990s, and today the estimated share Estonians living abroad is 20 per cent. ${ }^{2}$ Migration and globalization have had a stronger impact on Estonian than on larger speech communities, thus the topic of outmigration is often linked to the speculations of the "death" or "survival" of the Estonian language (Ehala 2009, 2010). The two latest language policy documents (Development Strategy of the Estonian Language 2004-2010, Development Plan of the Estonian Language 2011-2017) address outmigration as one of the main challenges to the future of the Estonian language. The state/supported initiative "Compatriots' Programme" was launched in 2004 to help the Estonian communities abroad to preserve their MT and make the returning to Estonia easier. The program was evaluated in 2015, revealing that the agents behind organizing MTT abroad are parents who expend enormous resources to organize and administer both MTT and the applications for subsidies from Estonia. MTT of Estonian abroad is thus heavily dependent on the existence of resourceful parents with high language self-esteem. These are parents who know their host country well enough to navigate the rules by which they have to play and possess organizational skills, a good portion of commitment and ability to form informal associations, virtues that Soviet education did not nurture (Annist 2015).

Already in 2001 Joshua Fishman noted in his ethnolinguistic vitality theory the importance of taking agency and the ability to act collectively (Fishman 2001). Salikoko Mufwene, one of the critiques of the linguistic vitality theory, noted that language as a parasitic species totally depends on the behavior of its speaker (Mufwene 2004). Language choices are dependent on the language speakers' socio-economic behavior, which is why this should be an intrinsic part of the studies of language sustainability, including intergenerational language transmission and organizing of MTT. The endangerment discourse that has colored language political discourse in Estonia also in the post-Soviet years has focused on language rather than language users and their behavior. The discourse of endangerment (Heller, Duchēne 2007) also influences the development of the "Compatriots Programme" (2004), which is administered by the Ministry of Education and was until 2014 focused mainly on supporting educational projects, where teaching of Estonian is at the core of the activity. Besides that, it supported Estonian language teacher training activities, thus defining MTT abroad as a serious business consisting of classes with children and teachers. Activities related to (language) community development abroad are not seen as part of MTT and not supported directly, although the Ministry of Culture supports activities related to the preservation of Estonian culture abroad. 
The discourse of preservation rather than development may be problematic, given that the Estonians migrating from Estonia are increasingly young people who move for studies or work experience. The younger generations live in a world of multiple choices and identity options, and promoting ancestral traditions alone will not work if their language practices are to be changed (Mufwene 2004). The post-traditional and reflexive societies of Europe (Giddens 1999) have open societal structures that promote and demand individual agency and reflexivity. Development in these societies is achieved through reorganization and redefining central issues and people are less concerned about the precedents set by earlier generations, since they have more choices due to the greater flexibility of law, social structures and public opinion. Language groups organizing to fight for their rights are on the one hand part of the social movements typical of reflexive modernization (Bech 2009), while on the other hand they are freer in defining what rights and activities they want to preserve. In this context there is also an increasing need to redefine MTT of Estonian abroad, recognizing that there is no one single option, but a multitude of options, depending on the host society.

\section{Estonians in Denmark}

Estonians started to arrive in Denmark mainly as a result of the Third Wave of Migration in the beginning of the 21st century, when Estonia entered the EU (in 2004). Estonians are the smallest language group among the approximately 200 languages spoken in Denmark ${ }^{3}$, living mainly in the capital but also scattered all over Denmark (Teral, Allik 2010) with only limited community support and mouth-to-mouth information distribution. The Estonian community in Copenhagen is the largest and lives rather densely. Since 1992 the society Eesti Kodu ('Estonian Home') ${ }^{4}$ has existed with varying degrees of activity; its most active period was before and after the regaining of independence in 1991. Today, the society no longer plays a central role in uniting the Estonian community in Copenhagen, as cheap travelling options and social networking technologies make it possible to stay in touch with friends regardless of their location. The group of Estonians in Denmark increasingly consists of students, who are part of the new transnational youth mobility. One of the reasons why Estonian students choose Denmark are the favorable conditions, where all students from EU can receive the state's study support (SU, Statens Uddannelsesstøtte) from the Danish state (Ligestilling efter EU-retten). For this group the reasons for meeting with other Estonians are different and no longer ethnicity-based, but rather based on the common social situation of being a student. Estonian students in Copenhagen and Southern Sweden meet frequently in either Lund or Copenhagen. In Copenhagen the Gorki Café-Bar is a meeting point for students from Eastern Europe selling beers from different Eastern European countries, including Estonia. Most recently, the day of restoration of Estonian Independence in 1991, August 20, was celebrated spontaneously at Gorki Café-Bar with an announcement made over social media attracting various visitors including even the Estonian Ambassador ${ }^{5}$. Many of these students stay in Denmark after studies to seek employment, thus creating new members of the diaspora here.

\footnotetext{
3 It is not possible to give an exact number of languages spoken in Denmark, but the number is estimated

4 Eesti Kodu. www.eestikodu.dk (7.3.2017).

525 years of Estonian Independence! Taasiseseisvumispäev at Gorki! https://www.facebook.com/ events/1074674222585646/ (7.3.2017).
} 


\section{The MTT of Estonian in Copenhagen}

The issue of ethnic affiliation and how to preserve one's language and culture appears in many cases first when one's children are born and the parents feel they need support for developing their children's Estonian skills. Although some teachers had previously offered classes in Estonian to grownups and children, the first parent community initiated MTT began in 2013 when a group of Estonian-speaking parents founded the Society of Estonian School and Kids' Club in Copenhagen (Kopenhaageni Eesti Koolija Lasteklubi Selts). The aim was simultaneously to form a society for Estonian children where they can meet and that can organize events for Estonian children, and to work towards tracking down 12 children interested in MTT in Estonian in Copenhagen. According to the existing requirements, 12 children from one language group have to apply for MTT in a municipality before the municipality initiates the service and employs a teacher (see Modersmålsundervisning). In reality, as was mentioned above, the MTT is only organized in two municipalities in Denmark, the capital Copenhagen and the second-largest city Aarhus (Daugaard 2015). The organizing work of the society led in 2015 to the formation of the first MTT class in Estonian under Modersmålsskole. The Society furthermore organizes annual events and retreats for Estonian families with children, and from 2015 Estonian Camps are organized every year in May. During the first camp in 2015 with 30 participating families, the Estonian parents were asked to fill out a questionnaire asking about their knowledge of and interest for the MTT for their children, and 24 participants turned in their answers. All participants had professional or higher education and were employed.

The results revealed that only those parents living in the Copenhagen area had heard about the option for municipally subsidized MTT of Estonian as an EU language, but did not know what they had to do to apply for it. Some said they were worried about how it would affect their kids' Danish competence. Only three considered that the aim of the MTT should be that their child would learn grammatically correct Estonian, while 20 agreed that MTT was first and foremost about community building that would bring their children together with other Estonian kids in Denmark, creating a space of positive belonging in the Estonian-speaking community in Denmark. The majority had had difficulties with making their kids want to speak Estonian, even if they understood it. 17 parents stated that the Estonian state should co-finance the MTT of Estonian, and 23 thought that the Danish state should participate (multiple answers were possible to this question). All parents stated that Estonian should be taught to preserve the link to Estonia, so children could move freely between Estonia and Denmark and might choose Estonia as the place of their future studies or work. The replies indicated that parents' understanding of MTT was shaped by ideologies and infrastructure in both countries, but is also colored by their own experience. The majority saw the state as the main agent in initiating and financing MTT, while they agreed that the community development aspect of MTT (that they have to act as a group to make organization of MTT possible) was necessary to make their kids speak Estonian. Some parents indicated that they tried to find a MT teacher earlier, but were turned down because of their kids' poor Estonian reading and writing competences, since the available teacher had to use textbooks designed for Estonian children in Estonia. Some indicated that 
although classes in Estonian were available with an Estonian teacher, they wanted more activity and socializing-focused MTT.

Since an MTT class could be offered only if 12 children from the same language group within the same municipality applied for it, the MTT became possible first when a group of parents took the initiative to track down the kids, communicate with their parents and coordinate the application process in order not to miss the annual deadline. The municipally subsidized Estonian MTT started in Modersmålsskolen in September 2015 with 12 children aged 7-12 meeting once a week for 3 hours. The Mother Tongue School has existed for a year and the school headmaster admitted that finding the information and applying for the opening of the first MTT class was cumbersome, but once it was organized, the parents of this language group were informed automatically that the class existed every spring. This structural deficiency functions as a gatekeeping mechanism because the municipality will most likely not have resources to finance MTT of all potentially interested. The quality of the service on the other hand depends on further growth: "If we have 20 and not 12 kids in a German class, we can consider splitting up the group into advanced and new-beginners." (HM). The most important organizational support that the school can give is the development of the professional identity of the MT teachers and training their competences: "I am very interested in developing the concept of MTT further, to gather and analyze the knowledge that our teachers have from their experiences, best practices etc." (HM).

The present Estonian MT teacher has served in this position for a year. For her, the biggest challenge was to start from scratch and to define what the MTT of Estonian should be about.

When I started I had my two hands and Google. [---] I could not use all the material available in Estoniain since these stories do not fit into the context here and the kids do not get the jokes and the allusions. Estonian materials teach the structure of the language while kids here need texts that have more simple language and are more playful, task-oriented and creative. Danish kids learn a lot through playing games [---] I use pre-school texts, although the kids here are 9-10 years old [---] In the first lessons I taught the kids as if they were Estonian kids. Then I realised that, no, they are Danish kids, who live in Denmark, speak Danish and behave like Danish kids. Then I first got to know them for real. [---] Estonian kids sit in a row, facing the blackboard; Danish kids sit around group tables because they are taught to work in teams and cooperate, and this of course means that they speak a lot in the class. [---] I have to work hard to get their attention. (ET)

The evaluation of the Estonian "Compatriots' Programme" (2004) also indicates that there is a need for country-specific, age and skills-differentiated teaching material and special training in multicultural teaching and communication for teachers of mother tongue abroad (Aksli et al. 2015). Although the Estonian teacher admitted that she appreciates having colleagues and a school that organizes the training of MT teachers, she does not feel that MT teachers at the Mother Tongue School have much in common or a common identity as suggested by the headmaster. The cultures and languages present are too different. "The only thing we have in common is the challenge we face with kids behaving in a Danish way in our classes, they are noisy 
and active" (ET). The most important development that has happened during the year is what has happened with the kids.

In the beginning they were afraid of speaking in the class and did not understand why they are here and why they have to learn the language. After having met every week, learning and playing together, they develop a feeling of commonness and community. (ET)

The MT teacher also indicated that she has received the most important professional support from the annual meetings of MT teachers of Estonia abroad ${ }^{6}$.

We [Estonian teachers abroad] face the same professional challenges of having to teach Estonian to children of about the same age, without having appropriate teaching material that fits the age group and language level [---], which binds us together in the same professional identity [---] we have the same feeling of a mission to do that work. (ET)

The Estonian teacher in Denmark has thus to face multiple challenges. One's first challenge, common with other MTT teachers, is how to teach kids who are used to Danish teaching methods and philosophy. The other challenge, common with other Estonian teachers abroad, is the lack of language teaching materials for Estonian children. This complexity demands a good deal of professional self-esteem, organizational talent, wit and courage to deal with it systematically: "I have profited greatly from my leadership experience and present studies in change management in managing the classroom challenges" (ET). Based on her experience, the teacher concluded that the organisational talent and the ability to embrace children's transnational identity and imperfect language have been crucial to making the MTT work. She also saw her important mission in making kids feel comfortable in the MTT space, not to be embarrassed about their language or about what they do not know or understand about Estonian culture. When I asked her to define what MTT of Estonian means for her, she replied: "It is not about the grammar, it is about the feeling of belonging or familiarity to Estonia, of having something in common [with other Estonians]".

\section{Discussion - MTT for the few resourceful?}

The present paper positioned the MTT of Estonian abroad within the broader context of changing patterns and types of migration and mobility in the 21st century (Castels, Miller 2009), forces that decentralize the state's agency and power in language policy issues like language acquisition planning (Brown et al. 2017). During the last decade we have witnessed several state initiatives that aimed to support the preservation of Estonian language in the increasing number of Estonian communities abroad. The main objective of the present paper is to exemplify a need for further qualitative and micro level analysis of how the MTT is actually organized (or why it is not organized) in the different communities. I claim that MTT is a transnational phenomenon that on the one hand is shaped by language policy and sociolinguistic settings in both host and home country. MTT for transnational

6 The organisation is called VÄLEK, Estonian schools outside of Estonia, and the communication is organised through the Facebook site https://www.facebook.com/groups/338388539586219/?fref=ts (7.3.2017). 
children abroad on the other hand also shapes and to some extent redefines what language acquisition is about and how it should be taught. Using the MTT of Estonian in Copenhagen as an example, I analyzed how the conceptual and infrastructural development of MTT in Denmark has been formed by the migration patterns typical for the 2oth century, but is now changing yet again due to the new inner EU migration, where the country of origin is often an active co-agent in forming the MTT. By becoming the official EU language, the status of Estonian in Denmark has changed from tolerance to promotion oriented (May 2015). However, claiming the right to MTT presupposes readiness to take language political agency. This study, as well as other recent studies, demonstrate that Estonians are not used to taking language political agency in language acquisition matters, and that they might even feel alienated from Estonian if they or their children do not speak it correctly. This feeling presents an easy route to giving up Estonian. What the communities need to experience and what the policy initiatives may need to address more is the ownership of the language, including a tolerance for different versions of Estonian and different ways of being Estonian. The state could more explicitly involve the experiences and ideas of Estonian teachers and communities abroad in developing teaching materials and the concept of Estonianness. The reality is that the Estonian language has become a transnational language used by people with multiple ethnic affiliations. The question is how this can be addressed better in Estonian language acquisition planning.

\author{
Abbreviations \\ ET Estonian MT teacher \\ HM Head of Modersmålsskolen \\ MT mother tongue \\ MTT mother tongue tuition
}

\title{
References
}

Aksli, Merli; Aruoja, Kertu; Lees, Kadri; Käger, Maarja; Sammul, Marek; Vahaste-Pruul, Sille; Tatar, Merit; Themas, Aivi; Varblane, Uku 2015. Rahvuskaaslaste programmi mõju-uuring. [Impact Evaluation Study of the "Compatriots' Programme 2009-2013".] Tartu: Tartu Ülikool, RAKE.

Annist, Aet 2015. Formal crutches to broken sociality. - Jeremy Morris, Abel Polese (Eds.), Informal Economies in the Post-Socialist Spaces. Palgrave Macmillan, 95-113.

Annist, Aet 2016. Elu mõtet kolides. Hargmaised eestlased ja ilmajätu varjud. [Moving the meaning of life. Transnational Estonians and the feeling of deprivation.] - Vikerkaar, august 2016. http://www.vikerkaar.ee/archives/19541 (7.3.2017).

Barry, Brian 2001. Culture and Equality: An Egalitarian Critique of Multiculturalism. Cambridge, MA: Harvard University Press.

Bech, Ulrich 2009. World at Risk. Cambridge: Polity.

Brown, Kara D.; Koreinik, Kadri; Siiner, Maarja 2017. Introduction: Spatial and temporal reconsiderations. - Maarja Siiner, Kadri Koreinik, Kara D. Brown (Eds.), Language Policy beyond the State. Springer: Amsterdam, 1-24.

Canagarajah, A. Suresh 2005. Dilemmas in planning English/vernacular relations in postcolonial communities. - Journal of Sociolinguistics, 9 (3), 418-447. https://doi. org/10.1111/j.1360-6441.2005.00299.x 
Castels, Stephen; Miller, Mark, J. 2009. The Age of Migration: International Population Movements in the Modern World. Basingstoke, United Kingdom: Palgrave Macmillan.

Cronin, Michael 1995. Altered States: Translation and Minority Languages. - TTR: Traduction, terminologie, rédaction, 8 (1), 85-103.

Cummings, Jim 2000. Language, Power and Pedagogy. Bilingual Children in the Crossfire. Clevedon: Multilingual Matters.

Daugaard, Line Møller 2015. Sproglig praksis i og omkring modersmålsundervisning. [Language practice in and about mother tongue tuition.] PhD thesis. University of Århus.

Egelund, Niels 2012. Northern Lights on PISA 2009 - focus on reading. Nordic Council of Ministers: Copenhagen. https://doi.org/10.6027/tn2012-501

Ehala, Martin 2009. Etnolingvistiline jätkusuutlikkus ja seda mõjutavad tegurid. [Ethnoilinguistic sustainability and factors influencing it.] - Jaan Ross, Arvo Krikmann (Eds.), Humanitaarteadused. Teadusmõte Eestis V. Eesti Teaduste Akadeemia, 19-34.

Ehala, Martin 2010. Keel ja ühiskond. Väliseesti kogukondade jätkusuutlikkusest. [Language and society: the sustainability of Estonian communities abroad.] - Kristiina Praakli, JüriViikberg (Toim.), Eestlased ja eesti keel välismaal. Tallinn: Eesti Keele Sihtasutus, 59-91.

Fishman, Joshua 2001. From theory to practice. - Joshua Fisman (Ed.), Can Threatened Languages be Saved? Clevedon: Multilingual Matters, 451-483.

Giddens, Anthony 1991. Modernity and Self-Identity. Self and Society in the Late Modern Age. Polity Press.

Glick Schiller, Nina; Basch, Linda; Blanc-Szanton, Cristina 1992. Transnationalism: A New Analytical Framework for Understanding Migration. Annals of the New York Academy of Sciences 645, 1-24.

Heller, Monica; Duchēne, Alexandre 2007. Discourses of endangerment: Sociolinguistics, globalization and social order. - Alexandre Duchēne, Monica Heller (Eds.), Discourses of Endangerment. Ideology and Interest in the Defence of Languages. London: Continuum, 1-13.

Holmen, Anne 1997. Dansk som andetsprog. [Danish as second language.] - Sprogforum, 9 (3), 22-26.

Holmen, Anne; Normann Jørgensen, Jens 2010. Skærpede holdninger til sproglig mangfoldighed i Danmark. [Negative attitudes towards language diversity in Denmark.] Jens Normann Jørgensen, Anne Holmen (Eds.), Sprogs status i Danmark 2021. [Status of languages in Denmark 2021.] Københavnerstudier i tosprogethed, 58, 87-105.

Hult, Francis; Pietikäinen, Sari 2014. Shaping discourses of multilingualism through a language ideological debate. The case of Swedish in Finland. - Journal of Language and Politics, 13 (1), 1-20. https://doi.org/10.1075/jlp.13.1.01hul

Kalmus, Veronika 2003. Is interethnic integration possible in Estonia? Ethnopolitical discourse of two ethnic groups. - Discourse and Society, 14 (6), 667-697. https://doi. org/10.1177/09579265030146001

Keskpaik, Kadri Saskia 2013. Talendid koju! Aga kes on talendid ja kus on kodu? ["The talented come home!" Who are the talented and where is home? On the mobility of Estonian People.] Uunpublished Master's Thesis, University of Tartu. http://hdl. handle.net/10062/31666

Koreinik, Kadri; Praakli, Kristiina 2017. Emerging language political agency among Estonian native speakers in Finland. - Maarja Siiner, Kadri Koreinik, Kara D. Brown (Eds.), Language Policy beyond the State. Amsterdam: Springer, 81-98.

Kramsch, Claire (Ed.) 2002. Language Acquisition and Language Socialization. Ecological Perspectives. London: Continuum.

Kristjansdóttir, Bergthora 2006. Evas skjulte børn. Diskurser om tosprogede elever i det danske nationalcurriculum. [Evas secret children. Discourses on bilingual children in the Danish national curriculum] Unpublished Ph.d.-thesis. Danish Pedagogical University. 
Kristjansdóttir, Bergthora; Holmen, Anne; Michael, S. Pedersen 2008. Modersmålet: en resurse for de priviligerede. - Sprogforum, 13 (43), 7-15.

May, Stephen 2015. Language rights and language policy: Addressing the gaps between principles and practices. - Current Issues in Language Planning, 16 (4), 355-359. https://doi.org/10.1080/14664208.2014.979649

McCarty, Theresa 2011. Introducing Ethnography and Language Policy. - Theresa McCarty (Ed.), Ethnography and Language Policy. NY: Routledge, 1-29.

Mufwene, Salikoko 2004. A Language birth and death. - Annual Review of Anthropology, 33, 201-222. https://doi.org/10.1146/annurev.anthro.33.070203.143852

Nieswand, Boris 2014. The burgers' paradox: Migration and the transnationalization of social inequality in Southern Ghana. - Ethnography, 15 (4), 403-425. https://doi. org/10.1177/1466138113480575

Parkvall, Mikael 2016. Sveriges språk i siffror. Stockholm: Morfem.

Pauwels, Anne 2007. Managing and Maintaining Minority Languages in the Era of Globalization. - Anne Pauwels, Joanne Winter, Jo Lo Bianco (Eds.), Maintaining Minority Languages in Transnational Contexts. Palgrave Macmillan, 1-12.

Pietikäinen, Sari; Pitkänen-Huhta, Anna 2014. Dynamic multimodal language practices in multilingual indigenous Sámi classrooms in Finland. - Durk Gorter, Victoria Zenotz, Jasone Cenoz (Eds.), Minority Languages and Multilingual Education: Bridging the Local and the Global. Dordrecht: Springer, 37-157.

Raag, Raimo 1999. Från allmogemål till nationalspråk. Språkvård och språkpolitik i Estland från 1857 till 1999. [From a peasant language to a national language. Language planning and language policy in Estonia from 1857-1999.] Studia Multiethnica Upsaliensia 12. Uppsala: Acta Universitatis Upsaliensis.

Siiner, Maarja 2010. Hangovers of globalisation. A case study of laissez-faire language policy in Denmark. - Language Problems and Language Planning, 34 (1), 43-62. https:// doi.org/10.1075/lplp.34.1.03sii

Siiner, Maarja 2012. Towards a more flexible language policy. A comparative analysis of language policy design in Denmark and Estonia. Dissertationes de mediis et communicationibus universitatis Tartuensis 17. Tartu: Tartu University Press.

Skutnabb-Kangas, Tove 2000. Linguistic Genocide in Education - or Worldwide Diversity and Human Rights? Mahwah, NJ: Lawrence Erlbaum Associates.

Sonntag, Selma K.; Cardinal, Linda 2015. State traditions and language regimes: Conceptualizing language policy choices. - Linda Cardinal, Susan K. Sonntag (Eds.), State Traditions and Language Regimes. Montréal and Kingston: McGill- Queen's University Press, 3-28.

Tammaru, Tiit; Eamets, Raul 2015. Contemporary emigration: Trends, causes and impact on Estonia's development. - Raivo Vetik (Ed.), Escaping the Traps? Estonian Human Development Yearbook 2014-2015. Tallinn: Estonian Cooperation Assembly, 109-118.

Teral, Marika; Allik, Mari 2010. Eestlased ja eesti keel Taanis. [Estonians and Estonian language in Denmark.] - Kristiina Praakli, Jüri Viikberg (Eds.), Eestlased ja eesti keel välismaal. Tallinn: Eesti Keele Sihtasutus, 503-517.

Timm, Lene 2009. The case of Denmark: An example of bad practice in intercultural education. - International Education, 20 (4), 385-390. https://doi. org/10.1080/14675980903352035

Timm, Lene 2007. Danmark har ondt in modersmålet. [Mother-tongue teaching in Denmark hurts.] Dokumentations- og rådgivningscentret om racediskrimination.

Torpsten, Arne C. 2012. Mother-tongue and multilingual education. Creating communities: Local, National and Global. Selected Papers from the fourteenth Conference of the Children's Identity and Citizenship in Europe, 153-160.

Vertovec, Steven. 2001. Transnationalism and identity. - Journal of Ethnic and Migration Studies, 27 (4), 573-582. https://doi.org/10.1080/13691830120090386 


\section{Web references}

25 years of Estonian Independence! Taasiseseisvumispäev at Gorki! https://www.facebook. com/events/1074674222585646/ (7.3.2017).

Compatriots' Programme 2004. https://www.hm.ee/en/activities/estonian-and-foreignlanguages/programmes (7.3.2017).

Development Strategy of the Estonian Language 2004-2010. https://www.eki.ee/keelenoukogu/strat en.pdf (7.3.2017).

Development Plan of the Estonian Language 2011-2017. https://www.hm.ee/sites/default/ files/eestikeelearengukavainglise.indd .pdf (7.3.2017).

$\mathrm{ECD}=$ Council Directive 77/486/EEC of 25 July 1977 on the education of the children of migrant workers. http://publications.europa.eu/en/publication-detail/-/publication/ b899a4e4-96fo-4370-bc4f-78fb93d42027/language-en (26.3.2017).

Eesti Kodu. www.eestikodu.dk (7.3.2017).

Ehala, Martin 2014. In search of the true Estonian. http://estonianworld.com/opinion/insearch-of-the-true-estonian/ (7.3.2017).

Ligestilling efter EU-retten. http://www.su.dk/su/udenlandsk-statsborger/ligestilling-eftereu-rettens-regler/ (7.3.2017).

Modersmålsundervisning. http://www.kk.dk/modersmaal (7·3.2017).

Eestlased välismaal. https://statistikaamet.wordpress.com/tag/eestlased-valismaal/ (7.3.2017).

VÄLEK(Välis-Eesti koolid). https://www.facebook.com/groups/338388539586219/?fref=ts $(7 \cdot 3 \cdot 2017)$.

Maarja Siiner (University of Oslo) studies migration and increasing multilingualism in the Norwegian society as a challenge to the Norwegian health care institutions. Her previous research includes furthermore studies of language management in Swedish multinational companies operating in Estonia, and cross-country comparisons of the interrelatedness of language policy developments and the democratization and decentralization processes in Scandinavia and Baltics.

Æbblestien 2, 2300 Copenhagne S, Denmark

maarja.siiner@iln.uio.no 


\section{HARGMAISE KEELEPOLITTKA SÜND. EESTI KEELEÕPPE KORRALDAMISE VÕIMALIKKUSEST VALISMAAL TAANI NÄITEL}

\section{Maarja Siiner}

Oslo Ülikool

Hargmaisus, kasvav väljarändajate arv ja sellega ka eesti keele rääkijate hulk välismaal on jätnud oma jälje eesti keelepoliitikale. Kui varem uuriti peamiselt seda, kuidas eesti keel muukeelses kontekstis muutub, siis viimasel kümnendil on riik asunud aktiivselt toetama eesti keele jätkuvat kasutamist välismaal, rahastades rahvuskaaslaste programmi abil haridusprogramme. Kuid millised faktorid määravad selle, kas uus eestlaste põlvkond oskab ja tahab eesti keelt rääkida? Artikkel hindab etnograafilises ja sotsiolingvistilises võtmes Kopenhaagenis kolm aastat tegutsenud Eesti Kooli ja Lasteklubi näitel, millised on keelekasutust soodustava tegevuse reaalsed väljakutsed. Selle mõistmiseks on vaja analüüsida nii Eesti kui Taani keelehariduse poliitikat, aga ka seda, kuidas hargmaisus mõjutab uute põlvkondade suhet emakeelega.

Võtmesõnad: keelepoliitika, hariduspoliitika, emakeele didaktika, keelekontaktid, Taani, eesti keel 